\title{
Memahami Persoalan Palestina-Israel dari Perspektif Islam
}

\section{Suswanta}

Jurusan IImu Pemerintahan, Fakultas IImu Sosial dan Politik, Universitas Muhammadiyah Yogyakarta

Ringroad Barat Tamantirto, Kasihan, Bantul 55183

Email:suswanta@umy.ac.id

\begin{abstract}
The difficulty in reconciling the Palestine and Israel conflict was because of political-ideology claims and theological claims. Theological claims in the conflict are very subjective and not easy to be solved by formal and structural diplomacy. The approach in theological side is the most dangerous engineered by Israel to occupy Palestine land. The effort to dismantle the engineering and imagination about the promised land as the form of scripture politicization still needs to be done until those facts become wider public discourse.

Keywords:ghanimah, legitimacy, evangelical country, promised land, Zionism
\end{abstract}

\begin{abstract}
Abstrak
Kesulitan mendamaikan konflik Israel dan Palestina terjadi karena klaim-klaim politik-ideologi dan klaim-klaim teologis. Klaim teologis dalam konflik tersebut bersifat sangat subyektif dan tak mudah diselesaikan oleh diplomasi formal dan struktural. Penghampiran pada sisi teologis merupakan rekayasa paling berbahaya yang dilakukan Israel untuk menduduki tanah Palestina. Upaya untuk membongkar rekayasa dan imajinasi tentang tanah yang dijanjikan sebagai bentuk politisasi ayat suci tetap harus dilakukan sampai fakta tersebut menjadi wacana publik yang luas.

Kata kunci:ghanimah, legitimasi, negeri Injili, tanah yang dijanjikan, zionisme
\end{abstract}

\section{PENDAHULUAN}

Dalam sejarah, tidak ada persoalan yang memerlukan kajian, diskusi dan perdebatan sebagaimana persoalan Palestina.. Juga, tidak ada persoalan yang demikian kompleks dan rumit seperti halnya persoalan Palestina. Dari segi diskusi dan pembahasan, sudah banyak buku-buku ataupun seminar yang mengkaji dan membahas Palestina. Berbagai macam makalah, selebaran dan publikasi telah dibuat, baik dari pihak Muslim, Yahudi maupun pihak lain. Kesemuanya berusaha mengupas masalah ini, baik menyangkut sebab-sebabnya, maupun cara penyelesaiannya
Adapun dari segi kompleksitas dan kerumitan masalahnya tampak dari kekeliruan sebagian masyarakat dalam melihat krisis Palestina, antara lain kesalahan dalam mendeskripsikan fakta mengenai persoalan Palestina. Salah satu bukti kesalahan misalnya, adanya pihak yang mendeskripsikan persoalan Palestina sebagai persoalan bangsa yang terusir, yang harus dikembalikan ke tanah mereka, dipindahkan atau ditempatkan kembali di tempattempat lain. Dalam hal ini, Israel telah mengklaim wilayah Palestina sebagai tanah yang dijanjikan oleh Tuhan untuk mereka dan mereka datang ke Palestina sekedar untuk memenuhi janji Tuhan. Benarkah 
demikian ? Juga bagaimana masalah Palestina dalam pandangan Islam?

Tulisan ini bermaksud membuktikan kesalahan klaim Israel dan mencoba menjelaskan masalah Palestina dalam perspektif Islam, tentu sebatas pengetahuan yang dimiliki penulis.

\section{PEMBAHASAN}

\section{KLAIM ATAS NAMA AGAMA DAN KEDUSTAAN ISRAEL}

Menurut Roger Geraudy, kedatangan orang Yahudi ke wilayah Syam (wilayah yang didudukinya sekarang) memang didorong oleh semangat keagamaan.(Roger Geraudy:2000). Zionisme sebagai gerakan agama menginginkan gunung Zion-yang kebetulan terletak di wilayah Syam-sebagai tempat suci bagi orang Yahudi seluruh dunia. Keinginan ini kemudian dimanfaatkan oleh Zionisme sebagai gerakan politik yang menginginkan adanya sebuah negara bagi orang Yahudi seluruh dunia. Tempat yang semula diincar adalah Uganda atau Argentina. Mengetahui bahwa Zionisme sebagai gerakan keagamaan menginginkan gunung Zion yang berada di wilayah Syam sebagai pusat peribadatan Yahudi, maka gerakan Zionisme internasional juga menetapkan wilayah itu sebagai tempat berdirinya negara Yahudi yang diidamkannya menggantikan Uganda dan Argentina. Dengan demikian, keinginan orang-orang Yahudi untuk memiliki negara sendiri mendapatkan legitimasi secara agama. Hal ini diputuskan dalam Kongres Zionis di Bazel, Swiss, 1897. (George Lenczowski:1992)

Cita-cita untuk mendirikan negara Yahudi di tanah Palestina semakin kukuh setelah tercetus Deklarasi Belfour, 1917, yang menegaskan dukungan atas berdirinya negara Yahudi di Palestina. Terlebih lagi setelah Liga Bangsa-Bangsa pada tahun 1922 menempatkan wilayah Palestina di bawah protektariat Inggris, cita-cita berdirinya negara Zionis-Yahudi semakin mendekati kenyataan.

Gelombang pengungsian orang-orang Yahudi ke Palestina semakin besar setelah mereka - khususnya yang berada di Eropa semasa Hitler berkuasa di Jerman - dikejar-kejar untuk dimusnahkan. Selain itu, kedatangan mereka ke Palestina dikatakan menuju tanah yang dijanjikan Tuhan untuk mereka, yang terbentang dari Sungai Nil di Mesir sampai Sungai Eufrat di Irak (sekarang ini). Golda Mier, Perdana Menteri Israel pertama mengatakan bahwa "Negeri ini (Israel) berdiri semata-mata hanyalah sebagai akibat janji Tuhan sendiri.Oleh karena itu, meminta pengakuan atas keabsahannya tentulah merupakan tindakan yang menggelikan.” Senada dengan itu, Menachem Begin, Perdana Menteri Israel yang berhasil menggandeng Presiden Mesir Anwar sadat dalam Perundingan Camp David mengatakan "Negeri ini telah dijanjikan Tuhan kepada kita, dan oleh karena itu kita berhak sepenuhnya atasnya". Mosye Dayan, Jenderal Israel keji bermata satu mengatakan "Jika terdapat buku Injil, serta bangsa Injili, maka haruslah terdapat pula negeri Injili”. "Negeri ini merupakan rumah historis bagi bangsa Yahudi” demikian pernyataan dalam Memorandum Organisasi Zionis (1919) (Ismail Yusanto, 1996, hal. 186)

"Janji Tuhan" itulah kredo yang sering mereka (ideolog Yahudi) serukan untuk mencari justifikasi atas tegaknya negara Israel. Mereka juga menggunakan sejumlah dalil dari Injil untuk membenarkan tuntutan "hak suci" atas negeri Palestina. Di tambah lagi dengan istilah-istilah "Bangsa Pilihan", "Israel Raya” yang terbentang dari Sungai Nil (Mesir) sampai daerah aliran Sungai Eufrat (Irak), menjadikan mereka (orangorang Yahudi) seolah-olah telah melihat peta wilayah Palestina yang ditandatangani Tuhan untuk mereka.

Zionisme internasional telah melakukan pengesahan ideologis atas Palestina dengan dalih janji Tuhan kepada Nabi Ibrahim as., sebagaimana tertulis dalam Genesis xv, 18:" Pada hari yang sama Tuhan membuat perjanjian dengan Ibrahim sambil berkata, " Kepada keturunanmulah negeri ini Aku berikan, mulai dari sungai di Mesir sampai sungai yang besar, sungai Eufrat". Janji Tuhan kepada anak keturunan Ibarahim menurut mereka adalah janji Tuhan terhadap bangsa Israel. Mereka mengklaim bahwa anak keturunan Ibrahim adalah mereka (Israel). Di sinilah terdapat pembacaan dan penafsiran Injil secara tendensius dan terbatas pada bagian yang dapat digunakan untuk melegalkan tindakan penaklukan, penindasan, 
pengusiran dan pembunuhan. Padahal, semnagat Kitab Pernjanjian Lama sama sekali berbeda dengan hal itu. Dalam Genesis, xxiii, hal. 3-20, disebutkan bahwa Nabi Ibrahim (Abraham-versi mereka) yang anak keturunannya mereka klaim sebagai Israel sama sekali tidak memandang dirinya sebagi pemilik negeri Kanaan (sekarang Palestina). Di Hebron, dengan segala kerendahan hati dan ketinggian budinya, Nabi Ibrahim mengajukan permintaan kepada Ephron, orang dari suku Hittit, agar bersedia menjual tanahnya di Machpelah, untuk kuburan isterinya, Sarah (Ismail Yusanto:1996, hal. 187).

Zionisme terbukti telah melakukan dusta atas nama Injil. Janji Tuhan kepada keturunan Ibarahim dalam Injil sesungguhnya menyangkut tanggung jawab, bukan hak-hak istimewa. Tanggung jawab untuk menyerahkan dan menundukkan segala upaya manusia kepada tujuan dan maksud Tuhan. Zionisme Internasional telah menciptakan paradoks. yaitu pembunuhan dianggap sebagai tindakan suci, pengusiran, perampasan dianggap memenuhi hak historis.

Cendekiawan sekaligus pendeta yang sangat besar perhatiannya kepada keaslian kitab Perjanjian Lama, R.P. de Vaux, akhirnya harus mengakui bahwa kecuali apa yang dapat dibaca dalam Injil, " tidak akan dapat ditemukan rujukan yang eksplisit kepada para Bapak kaum Ibrani, tentang periode yang telah dihabiskan di Mesir, ataupun mengenai penaklukan wilayah Kanaan." Dengan demikian, pernyataan bahwa negeri Palestina adalah negeri yang dijanjikan Tuhan kepada mereka hanya muncul dalam naskah-naskah yang berasal dari kalangan mereka yang menyatakan bahwa diri merekalah yang berhak untuk menerima janji tersebut. Thomas Kiernan, seorang Antropolog mengatakan bahwa para ahli Antropologi menyimpulkan, bahwa orang Yahudi Eropa bagian Timur - tempat para pencipta Zionisme-hanya sedikit saja atau bahkan tidak ada sama sekali yang memiliki hubungan biologis dengan Palestina. Senada dengan Thomas Kiernan, Roger Geraudy mengatakan bahwa orang-orang Yahudi sama sekali tidak mempunyai keabsahan baik secara historis, Injili maupun yuridis untuk berdiri di tempat ia ditegakkan sekarang ini
(Palestina),

Jadi, tidak mungkin sama sekali mengkaitkan Israel dengan apa yang disebut "hak historis" sebagai bangsa yang pertama kali menduduki serta mendiami wilayah palestina. Kenyataan menunjukkan terdapat banyak suku bangsa yang sampai ke wilayah itu, bersamaan dengan orang-orang Aramean. Mereka menemukan di daerah itu orang-orang Kanaan "Asli", yaitu orangorang Hittit yang tinggal di sekitar Hebron, suku bangsa Maobit (yang bermukim di sekitar Laut mati). Pada saat bersamaan masih datang suku lain, yakni orang-orang Filistin. Mereka berasal dari daerah Laut Aegea. Metreka kemudian tinggal di antara gunung Karmel dan padang pasir. Merekalah yang kemudian disebut orang-orang Palestina. Orang Palestina adalah keturunan penduduk asli Kanaan. Mereka paling tidak telah tinggal di wilayah itu selam lima ribu tahun silam. Dengan demikian” penduduk pertama" negeri ini sesungguhnya adalah orang Palestina. Sejarah mencatat., orang-orang Ibrani (Apiru) ketika datang dari Mesir pada abad 13 SM dan kemudian bermukim di Palestina, adalah gerombolan penyerbu. Hanya setelah penempatan mereka di Kanaan pada abad 13 M, baru bisa disebut adanya bangsa Israel.

Dengan demikian kedatangan orang-orang Yahudi dari seluruh penjuru dunia ke Palestina, sesungguhnya lebih disebabkan karena pengejaran-pengejaran yang mereka alami di berbagai penjuru dunia, bukan karena kerinduan pada "negeri leluhur asal nenek moyang mereka”. Pada abad 15 orang Yahudi yang datang Palestina berasal dari Spanyol. Tahun 1854 terdapat 12.000 orang Yahudi di Palestina. Tahun 1882 akibat pengejaran terhadap orang-orang Yahudi, terutama di Rusia, terjadi imigrasi orang-orang Yahudi besarbesaran ke wilayah Palestina. Menjadi jelas bahwa orang Ibrani hanya merupakan salah satu unsur dari pencampuran bangsa-bangsa yang mendiami "daerah bulan sabit yang sangat subur itu." Oleh karena itu, semestinya mereka tidak mempunyai hak untuk menuntut sesuatu yang istimewa di tempat itu.

\section{PALESTINA DALAM PERSPEKTIF ISLAM}

Bagaimana sikap umat Islam terhadap pendudukan 
dan penguasaan tanah Palestina oleh Israel sekrang ini sangat ditentukan oleh pemahaman mereka terhadap kedudukan tanah Palestina itu sendiri. Sejarah tanah Palestina sesungguhnya adalah sejarah Islam. Wilayah itu dikuasai Islam dengan damai. Orang Nashrani sendiri yang secara suka rela pada tahun $636 \mathrm{M}$ menyerahkan kunci kota Yerusalem (saat itu disebut "Illia") kepada Khalifah Umar bin Khattab (penguasa Islam pada saat itu).

Diwakili tokohnya Pendeta Patriach Shafarniyus, kaum Nashrani Yerusalem bersama Khalifah Umar bin Khattab menandatangi suatu perjanjian yang dikenal dengan "Piagam Illia " atau "Perjanjian Umairah". Isi dari perjanjian tersebut adalah:

"Dengan Nama Allah, Maha Pengasih dan Maha

Penyanyang. Inilah yang diberikan hamba Allah, Umar

Amirul Mukminin, kepada penduduk 'Illia tentang

keamanan. Ia memberinya keamanan untuk jiwa dan

harta mereka, untuk gereja-gereja dan salib-salib mereka, juga untuk orang yang sakit dari mereka dan yang sehat, serta untuk seluruh komunitasnya...Dan tidak akan diizinkan tinggal bersama mereka, seorang pun dari orang Yahudi."

Umar bin Khattab, Khalifah kedua Islam setelah Abu Bakar melanjutkan gebrakan yang dilakukan Nabi Muhammad Rasulullah S.A.W. mengusir orang-orang Yahudi dari jazirah Arab. Umar juga melakukan hal yang sama atas permintaan orang-orang Nashrani di kota Yerusalem pada saat itu. Kini, sudah 14 abad berselang, seluruh dunia mengetahui bahwa Israel adalah perampas tanah Palestina- tanah suci umat Islam.Israel merampas tanah Palestina dengan dalih melaksanakan amanah Tuhan yag telah menjanjikan wilayah itu untuk mereka. Klaim yang sangat subyektif. Klaim tersebut dibantah keras oleh Roger Geraudy, Intelektual Kristen Perancis keturunan Yahudi yang kemudian masuk Islam. Menurutnya, Israel tidak memiliki legitimasi atas tanah Palestina baik secara historis, antropologis maupun Injilis. Dari hasil pengkajian sejarah tidak pernah ditemukan nenek moyang Yahudi yang tinggal di daerah itu, apalagi jika disebut sebagai bangsa yang pertama. Suku bangsa
Filistin justru yang lebih dulu tinggal di daerah tersebut. Secara antropologis terbukti bahwa orangorang Yahudi datang ke Palestina lebih akhir, karena mereka mengalami dispora setelah dikejar-kejar Nazi Juga, tidak ada dalil-dalil Injil baik dari Perjanjian Lama maupun Baru.yang menunjuk mereka (orangorangYahudi) harus tinggal di wilayah Palestina, apalagi secara paksa.

Tanah Palestina, ibarat tanah titipan, adalah amanah yang diberikan kepada umat Islam.Tanah Palestina erat kaitannya dengan nafas Islam. Palestina adalah kiblat pertama umat Islam. Shalat di Masjid Al Aqsha diyakini akan mendapatkan pahala 500 kali lebih banyak dibanding sholat di masjid biasa. Tanah Palestina adalah adalah tanah milik umat Islam, bukan milik perorangan, dan tidak bisa dimanfaatkan atau dimiliki oleh siapapun kecuali sesuai dengan hukumhukum syara' (hukum Islam). Islam memahami bahwa setiap negeri yang telah ditaklukan umat Islam tergolong ke dalam apa yang disebut " negeri yang diwariskan Allah untuk mereka”.

Sayyid Sabiq (dalam Kitab Fiqh As-Sunnah) membedakan antara ghanimah atau anfal dengan fa'i. Ghanimah atau anfal adalah harta benda milik orangorang non muslim yang dikuasai umat Islam dalam medan perang. Ghanimah tersebut bisa berupa tawanan perang atau sesuatu yang dibawa (manqul) seperti senjata, perbekalan, uang, perhiasan atau yang lainnya. Sementara, tanah yang didapatkan umat Islam melalui penaklukan suatu negeri tanpa kekerasan termasuk harta fa'i,bukan ghanimah. Berbeda dengan ghanimah yang bisa dibagikan kepada pasukan umat Islam, harta fa'i- tanah- pemanfaatannya diserahkan kepada umat Islam secara umum. Atau hasilnya disimpan di Baitul Mal-lembaga kas milik umat Islam dimasa Khilafah Islam-untuk kemashlahatan umat Islam. Setiap umat Islam berhak mendapatkannya hingga akhir zaman.

Dengan demikian, setiap tanah yang ditaklukan umat Islam Islam melalui jalan damai seperti tanah Irak-termasuk Kuwait, tanah Syam-termasuk Palestina, tanah daratan Hindia-termasuk Pakistan dan Kasymir, dan tanah-tanah Afrika Utara serta tanah-tanah lainnya 
yang statusnya serupa, seluruhnya merupakan fa'i selama-lamanya bagi umat Islam. Dengan kata lain menjadi hak umat Islam hingga hari Akhir nanti. Tanah itu juga disebut tanah Kharaj. Artinya hak milik tanah itu berada di tangan Baitul Mal(lembaga Kas milik umat Islam dimasa Khilafah Islam). Adapun pemanfaatannya dapat diambil oleh siapa saja yang menempati tanah tersebut dan yang menempati wajib membayar uang kharaj dengan jumlah tertentu kepada Baitul Mal. Ketetapan ini diyakini umat Islam berlaku kekal, tidak akan pernah berubah sampai hari kiamat tiba.

Kedudukan tanah Palestina sebagai tanah Kharaj penting untuk dikemukakan, agar menjadi perhatian umat Islam di seluruh dunia. Penyerahan tanah Palestina kepada Israel jelas merupakan pengkhianatan terhadap Allah SWT, Rasulullah SAW, Agama Islam, para Sahabat Rasul yang telah menjadikan tanah tersebut sebagai negeri umat Islam, juga merupakan pengkhianatan terhadap panglima Shalahuddin alAyyubi dan pasukannya yang telah mengembalikan tanah tersebut kepada umat Islam dari tangan kaum Nashrani. Dalam perpsektif inilah jihad bisa dipahami sebagai solusi untuk menyelesaikan masalah Palestina, dalam arti membebaskan seluruh wilayah Palestina dari cengkeraman Israel.

\section{KESIMPULAN}

Harapan bahwa pada suatu saat dapat kembali ke “Tanah yang Dijanjikan Tuhan” tidak akan pernah hilang dalam benak orang Yahudi. Kini mereka telah menguasai tanah tersebut setelah berjuang sekian lama. Dilihat dari perspektif ini, tidak mungkin Isreal akan memberi kemerdekaan untuk bangsa Palestina. Justru sebaliknya Israel akan "mengusirnya” demi mewujudkan "Israel Raya” yang membentang dari sungai Nil (di Mesir) sampai engan sungai Eufrat (di Irak). Sementara dalam perspektif Islam, tanah Palestina adalah tanah Kharaj, dalam arti tanah milik umat Islam selamanya. Dengan demikian dalam pandangan Islam, apa yang dilakukan Israel harus dilawan, karena tidak ada bukti secara sah alasan penguasaannya atas tanah Palestina. Dalam kerangka ini kita bisa memahami mengapa jihad dianggap sebagai solusi penyelesaian masalah Palestina.

\section{REFERENSI}

Geraudy, Roger, Mitos dan Politik Israel, Gema Insani Press, Jakarta, 2000

Husein, Machnun, et.all., Prospek Perdamaian di timur Tengah, Sebuah Tilikan Latar Belakang, Pustaka Pelajar, Yogyakarta, 1995

Hilal, lyad, Palestina:Akar Masalah dan Solusinya, Pustaka Thoriqul Izzah, Bogor, 1993

Jatmika, Sidik, AS Penghambat Demokrasi, Bigraf Publishing, Yogyakarta, 2000 Gerakan Zionis Berwajah Melayu, Wihdah Press, Yogyakarta, 2001

Katz, Jacob, Zionisme:Sejarah Pertumbuhan dan Perkembangan, Pustaka Progresif, Surabaya, 1996

Lenczowski, George, Timur Tengah di Tengah Kancah Dunia, Sinar Baru Algesindo, Bandung, 1992

Rais, Amien, Cakrawala Islam: Antara Cita dan Fakta, Mizan, Bandung, 1991

Sabiq, Sayyid, Al Ma'arif, Bandung, 1986

Kompas, Selasa, 27 juli 2004

\section{Lampiran:}

\section{Konflik Israel-Palestina dalam Tabel}

\section{TAHUN PERISTIWA}

1800 Terjadi migrasi pertama kaum Yahudi-Eropa ke Palestina. Saat itu juga lahir gerakan Zionisme yang akan menjadikan wilayah Palestina sebagai negara kaum Yahudi

1948 Yahudi memproklamasikan negara Israel. Israel terlibat perang dengan negara-negara Arab tetangga Palestina. Sekitar 700.000 rakyat Palestina terpaksa mengungsi. Israel berhasil menguasai wilayah sangat luas

1967 Perang enam hari. Mei 1967 Mesir menutup teluk Aqaba dari kapal-kapal Israel dan dimulainya mobilisasi melawan Israel. Suriah dan Yordan mendukung Mesir. Israel berhasil menguasai Dataran Tinggi Golan, Tepi Barat dan Jalur Gaza. 10 Juni 1967 perang berakhir dan PBB turun tangan

1979 Pertemuan Camp David. Mesir dan Israel mengadakan pertemuan untuk mengakhiri permusuhan di antara keduanya selama 30 tahun

1987 Dimulainya gerakan Intifadha bangsa Palestina melawan Israel di Tepi Barat dan Jalur Gaza. Tidak kurang 20.000 orang meninggal dunia dan cidera

1991 Pertemuan Madrid. Menlu AS, James Baker mengusulkan pertemuan perdamaian, Suriah dan Yordan setuju untuk datang

1993 Yasser Arafat dan PM Israel Yitzak Rabin menandatangani Deklarasi Prinsip-prinsip Perdamaian 
di Oslo (Perjanjian Oslo). Israel mengakui PLO dan memberikan otonomi terbatas. PLO menjanjikan perdamaian dan mengakhiri klaim teerhadap wilayah Israel

1994 Teracapai kesepakatan antara PLO dan Israel di Mesir. Hasil kesepakatan memerintahkan tentara Israel mundur 60 persen dari wilayah Jalur Gaza dan Kota Jericho di wilayah Tepi Barat

1995 Arafat dan Rabin menandatangi Perjanjian taba (Oslo II) di Washington, AS. Wilayah Otoritas Palestina diperluas ke Tepi Barat dan Jalur Gaza serta diizinkannya penyelenggaraan Pemilu di Palestina

1998 Di bawah tekanan AS, PM Israel Benyamin Netanyahu menandatangi Memorandum Wye River yang mengatur penarikan mundur lanjutan pasukan Israel dari Tepi Barat dan Jalur Gaza

1999 -September 1999, proses perdamaian di Timur Tengah berjalan kembali dengan penandatangan Memorandum Wye River yang diperbarui. -Desember 1999, proses negosiasi akhir palestina dan Israel menemui jalan buntu karena Israel membangun pemukiman Yahudi baru di wilayah Tepi Barat

2000 -Maret 2000, Israel melepaskan 2,1 persen wilayah Tepi Barat kepada Palestina. Negosiator keduanya kembali bertemu di Washington, AS untuk memulai kembali pembahasan status akhir Palestina. -25 Juli 2000, pertemuan perdamaian di Camp David, AS, berakhir tanpa hasil setelah dua minggu bernegosiasi. Kedua negosiator gagal mencapai formula penyelesaian masalah kota Yerusalem. September 2000, Intifadha untuk kedua kalinya terjadi antara warga Palestina dan tentara Israel

2002 Yasser Arafat kembali menandatangi keputusan yang menetapakan Kota Yerusalem sebagai Ibu Kota Palestina mendatang dan markas lembaga legislatif, eksekutif dan yudikatif bagi negara Palestina

2003 Pejabat tinggi Hamas Ismail al-haniyah, menyatakan gencatan senjata telah berakhir. Pernyataan itu dikeluarkan setelah Helikopter Israel menembakkan peluru kendali yang menewaskan Ismail Abu Shanab, salah seorang pemimpin Hamas

2004 -7 Januari, Palestina secara resmi menolak daftar dari Israel tentang 28 pemukiman yang harus segera dibongkar. Palestina menganggap langkah itu tidak tepat dan hanya sebagai tipu daya. Sebaliknya Israel berpendapat bahwa pembongkaran itu selaras dengan peta perdamaian rancangan PBB, Rusia, AS dan Uni Eropa. -23 Februari, Israel memboikot pengadilan internasional soal pembangunan pagar oleh Israel. Arafat mengatakan tidak mungkin ada perdamaian kecuali pagar dan tembok pembatas Tepi Barat-Israel tersebut dibatalkan.-9 Juli, Mahkamah Internasional di Den Haag memutuskan bahwa pembangunan pagar di
Tepi Barat illegal dan oleh karena itu harus dibongkar20 Juli, PBB mendesak Israel untuk menghancurkan dinding pemisah. Desakan PBB tersebut terungkap dalam Sidang Majelis Umum PBB dengan perbandingan suara 150 mendukung, enam menentang dan 10 abstain. Israel mengabaikan desakan itu dan memutuskan tetap akan membangun tembok 